\title{
The Impact of American Students and Teachers on Gulf Students' Academic Success
}

\author{
Ghadah Al Murshidi \\ UAE University, Al Ain, United Arab Emirates
}

\begin{abstract}
The study explores the impact of students' and teachers' support on Emirati and Saudi students at U.S. Universities. Based on a sample of 219 , a mixed methods approach was used to analyze responses from participants who responded to a questionnaire. The results of the questionnaire instrument reveal that almost half the number of Emirati students felt "comfortable" associating with students from the same region. Also, the survey shows that most Emirati and Saudi students were "very comfortable" and "comfortable" to discuss their challenges with their professors. The interviews results indicate that different communication skills might influence students' relationships especially if they come from different cultures. For instance, an Emirati student experienced ignorance from American students and a Saudi student emphasized the American students' preference to work with their American peers. However, Emirati and Saudi students try to get involved in group work with American students to get assistance.
\end{abstract}

Index Terms - social adjustment, identity adjustment, language adjustment

\section{INTRODUCTION}

A scan of the literature reveals little or no significant studies have been undertaken recently in the Gulf area and I believe research on the influence of students' and teachers' support on Emirati and Saudi students at U.S. Universities will be important to educators and policymakers. In recent informal conversations with a few international students at U.S. Universities, I learned that Arab students experience challenges and struggles in their first year compared to the succeeding years of study as they may lack certain cultural and linguistic capital that is necessary to successfully function in their disciplines, particularly at the doctoral level. These students are away from their families; therefore, they merge their social and academic lives. Most Emirati and Saudi students for example, are returning adult students who typically have interrupted their careers to earn degrees that permit them to return to their countries to help others to grow. Some of these students told me how they got shocked and lost when they did not get support in their academic work from their classmates, instructors or friends.

\section{LITERATURE REVIEW}

\section{Empirical Studies on Cross - Cultural Adaptation and Academic Socialization}

Scholars define academic socialization as a process in which students undergo a social and cultural transformation from one cultural and linguistic context to acquire academic writing skills in another context or language in order to become legitimate or proficient participants in a given academic discipline (Belcher, 1994; Canagarajah, 2002; Casanave, 1995, 2002; Hirvela and Belcher 2001; Ivanic, 1998; Ivanic and Camps, 2001; Lea and Street, 1999; Prior 1995). However, understanding the complexity of this concept improves with inclusion of "cross cultural adaptation" as anchored in multiple disciplines: anthropology, communication, psychiatry, psychology, sociology, sociolinguistics, and other related disciplines.

In a classic work, Kim (1988) presented a model of cross-cultural adaptation based on socio-psychological adjustment theory and situates cross-cultural adaptation in an integrative theory that emphasizes "stress-adaptationgrowth's" dynamics of cross-cultural experiences, which "bring about cultural strangers' gradual transformation toward increased functional fitness in the host milieu" (p. 200). Even though the literature on "socialization" and "adaptation" overlap in some respects, this exposition distinguishes the two and proposes ways to reconcile them in a unique study of academic socialization. According to Kim (1988), cross-cultural adaptation occurs when people from one culture move to a different culture, learn the rules, societal norms, customs, and language of the new culture. By bringing their existing thoughts, feelings, behaviors, and beliefs with them, a person integrates those into their new society while adjusting and accepting to the new standards, thereby creating a multicultural person. Kim (1988) relieves part of the confusion by theorizing that effective intrapersonal (cognitive, affective, and behavioral) and social (interpersonal and mass) communication activities are at the heart of successful adaptation (or socialization, for that matter) - along with individual background characteristics and the host country's environmental conditions.

The current need to study these perspectives arises from possibilities realized from current technological advances and student migration patterns. The contraction of time and space, acceleration of technological innovations, and globalization has created greater mobility and access to information. For example, in 2007, about 2.8 million 
international students were "mobile," 1 million more than in 1999. In other words, every year, the annual increase of mobile tertiary students to the U.S. universities is 4.6\%(UNESCO 2009). Of the numerous populations of students, $20 \%$ of the internationally mobile student population is United States enrollees (ACE 2009). The current study addresses this group of students.

Researchers such as Kim (1988) and others(e.g. Bloome, Carter, Christian, Otto, Shuart-Faris, 2005; Gumperz, 2001; Hymes, 1974; Barton and Hamilton, 1994, 1998; Gee, 2000) developed several theories that explain the phenomenon of academic socialization. Central to these theories is the idea that the concept of cross-cultural adaptation, which entails moving from one culture to another culture, usually (but not always) learning the rules, norms, customs, and language of the new culture encompass several social science disciplines, including anthropology, sociology and psychology. The limitation of the current research is however inclusive of only sojourners, those who travel to a culture for an extended time, but with projected limits - that is, ultimately plan to return to the home country. Such sojourners are international students or those on extended business assignments perhaps one to three years. Psychologists and communication scholars tended to focus on individual levels of adjustment, that is, the thought, emotional, and behavioral processes of adjustment (psychology), and the role of communication in both leading to "culture shock" or "cross-cultural transition stress," and in helping to reduce these stresses.

The notion of "culture shock" (Oberg, 1955) for example, summarizes the often dramatic effect of the adjustment experience. As a consequence, the tendency is toward automatic initiation of a series of psychological mechanisms to regain comfort, a feeling of security and positive thoughts. Even though the central interest of the research centers on academic socialization, a review the extensive literature, signals the necessity of attending to issues of cross-cultural adaptation, including stresses resulting from culture shock. In other words, a systemic approach within which the notion of adjustment (which involves psychological self-transformation) that incorporates forms of socialization (that is, social factors within the new culture, including the people contacted, known, interacted [e.g., particular interactions with staff members or other students] while trying to acclimate to this new environment) is necessary. And, as noted by Kagan and Cohen (1990), the terms adjustment, acculturation, and assimilation "are used interchangeably to denote behavior, value, and attitude changes associated with feelings of mental health and social integration" (p. 133). Therefore, the overarching quest of the research is to examine the mechanics and dynamics of individual adjustment processes within the academic environment, the sources of difficulty, and the reason some adjust more easily than others.

\section{Adjustment Complications of International Students}

Some studies on cultural adjustments of international students state that through social communication with hosts, international students have a better chance to develop skills and behaviors that can assist them adapt to their new cultural environment (Furnham and Bochner, 1986; Shaffer and Harrison, 2001). Other researchers indicate that international students often face problems with acculturation, and decreased access to their existing or familiar support systems add to the challenges (Charles-Toussaint and Crowson, 2010; Kagan and Cohen, 1990). However, research of Emirati and Saudi students' adjustment and assimilation in the United States is limited. Few studies explored the adjustment process of Emirati and Saudi students, who arrive in the country with myriad looming challenges, such as attitudes towards religion, language, study habits, dress code, and not to mention, food, all of which require adjustments

For these reasons, Emirati and Saudi students face many changes and difficulties in adapting to universities in the United States. Facilitating the adjustment of Emirati and Saudi students to college life has become an increasingly significant concern of administrators recently due to the negative influence of adjustment problems on student attrition (Al - Sharideh and Goe, 1998).

Cultural adjustment of international students is an important issue for educators and college administrators throughout the United States, mainly because of the negative impact of unsuccessful adjustment of the international students to the new environment. That lack of adjustment affects international students' academic careers, personal satisfaction, and general well-being. These students share feelings of anxiety, confusion, and homesickness, among others concerns. International students' cultural differences may hinder or delay their adjustments process.

Emirati and Saudi students seem to face many particular challenges since they are geographically distant from familiar environments and support, and English is not their mother tongue language. Students' experiences in the host country are different from their own cultures in terms of norms, roles, attitudes, values, and expectations, which create greater difficulties and stress (Al - Sharideh and Goe, 1998). Emirati and Saudi students may suffer from loneliness due to loosing of social ties with people in their native countries. Adding to these challenges, Emirati and Saudi students are expected to cope with the exigencies of their new social environments, meeting their personal needs, and performing satisfactorily in their academics.

Ward and Searle (1990, p. 210) proposed dividing adjustment into two aspects: physiological, which "refers to feelings of well-being and satisfaction," and socio-cultural, which "relates to the ability to 'fit in' in the host culture. Ward and Searle (1991) explained that sojourner adjustment has attracted three main theoretical positions for the aspects that influence the adjustment: clinical perspectives (e.g., personality, life events and social support), social learning models (e.g., acquiring appropriate skills and behaviors, cross- cultural experience and training), and social cognition approaches (e.g., variables such as attitudes, values, expectations and self-concept). All these dimensions and variables influence on the international students' adjustment.

\section{Social Adjustment}


Loneliness predicts a sojourner's psychological distress (Ward and Searle, 1991). Sojourners who feel helpless in a new culture might seek to communicate with those they believe can help them to find answers to their questions. Social support could reduce uncertainty as Albrecht and Adelman (1984, 1987a) defined "verbal and nonverbal communication between the recipients and the providers that reduces uncertainty about the situation, the self, the other, or the relationship, and the functions to enhance a perception of personal control in one's life experience" (1987a, p, 19). According to Adelman (1988), people also seek to feel they have control over a specific situation through social support, which influences the sojourner's psychological well-being (Ward and Searle, 1991).

When international students move to a new country, they lose their old support networks (e.g., family and friends), so they try to build new support systems. Some of the international students experience culture shock and feeling of anxiety that appear in their behavior. They try to avoid the native speakers of that country and look for company from their co-nationals (Church, 1982). To gain feeling safe in the new culture, some of the international students speak their native languages with their co-nationals, practice their cultural values and express their ethnicity.

Support from co-nationals can help relieve the homesickness and stress feeling that international students go through during the adjustment process. Also, through communication with co-nationals, the international students feel less stressful to realize that their co-nationals experienced similar problems when they had arrived (Bochner, 1981; Furnham and Bochner, 1982; Kim, 1987). According to Giordano and Giordano (1976), ethnicity fulfills a psychological need for security, identity, and a sense for historical continuity. Co-nationals represent a "low-risk informant"(Adelman, 1988, p. 188) who can offer answers, while reducing the student's uncertainty for affecting the relationship by the help-seeking process. In other words, international students feel more comfortable seeking answers from co-nationals that do not make judgment on them. Sojourners who have less support from their co-nationals, apparently, have greater problems of adjustment (Torbion, 1982). Kagan and Cohen (1990) believe that the relationships with co-nationals are significant to students; however, those relationships might negatively impact their cultural adjustment.

Living in a new culture with stressful conditions, internationals students might also seek the companionship of other new co-nationals (Wills, 1983), and to share resources and information to cope with their adjustment issues. In this kind of informal support groups, members self-disclose their fears and concerns and participate in their new community (Greenberg, 1980). Support systems among those who are experiencing similar cross-cultural stresses, however, could also interfere with satisfying the needs of these individuals (Fontaine, 1986). Stressed individuals can negatively influence those who are vulnerable (Adleman, 1986; Albercht and Adelman, 1984, 1987b), when sharing tensions and concerns. Also, co-nationals might unintentionally worsen the stress and anxiety of the new international students (Adelman, 1988).

Even though international students might benefit initially from the support of their co-nationals, eventually the international students will need to reduce their interaction and dependence on their co-nationals, and in turn increase their interaction with hosts in order to acquire the skills necessary to adapt successfully to the new environment. Limiting their interaction with hosts will only hinder learning the new language, values, and norms of the culture and will reinforce feelings of alienation(Aresberg and Niehoff, 1964; Garraty and Adams, 1959; Gullarhorn and Gullarhorn, 1966; Kang, 1972; Lundstedt, 1963). Insulation among national compatriots may also create protection from cultural change (Alberchet and Adelman, 1984), adding to the difficulty of acquiring skills necessary to adjust to the new environment. Essentially, communication with members outside the co-nationals group is significant for their integration (Kim, 1987).

In the beginning of an experience in a new culture, international students tend to avoid interacting with hosts and seek the company of co-nationals (Church, 1982); however, upon arrival, while the interaction with co-nationals is vital for new international students to feel supported, eventually, seeking interaction with hosts becomes equally significant. Apparently, detachment from one's co-national community eases cultural adjustment (Bruner, 1956; Kagan and Cohen, 1990; Masuda, Matsumoto, and Meredith, 1970; Montgomery and Orozco, 1984; Spiro, 1955; Weinstock, 1964; Yao, 1985), and the contact with representatives of the host culture positively facilitates cultural adjustment (Bruner, 1956; Fugita and O'Brien, 1985; Kagan and Cohen, 1990; Roskin and Edleson, 1984; Smith, 1976; Weinstock, 1964). Kagan and Cohen (1990) found that students who had close American friends were more likely to have an easier shift to the new culture than those without the same relationships.

\section{Identity adjustment}

Cultural identity is another factor that impacts the process of adjustment experienced by international students. Cultural identity is the mental framework through which individuals interpret social cues, choose certain behaviors, respond to their surroundings, and evaluate the actions of other people (Sussman, 2001). A logical prediction is that international experiences have tremendous impact on identity formation or identity adjustment. According to Brown (2009), identity's basis is "membership of many different and simultaneously overlapping demographic categories such as religion, culture, and nationality" (p. 60). To illustrate this in practical terms, Brown (2009) showed that Indonesians share a common language, religion, and culture. Indonesian Muslims identified themselves with a shared religion, while Chinese, a major group in the country, gained further distinction from their inter-group's Chinese language (besides speaking Indonesian), a distinct marker based on a shared culture (Brown, 2009).

The situation is not different in the Gulf region. For example, to maintain cultural identity and native language, a general reluctance existed to teach English throughout the early history of education in the Kingdom of Saudi Arabia 
(KSA), (Elyas and Picard, 2010). Not until 2003 was English included in the curriculum of all primary schools in KSA, and then only after considerable international pressure (Elyas, 2008a, b), and although English is generally accepted in KSA, debates still rage as to instructional methodology (Elyas and Picard, 2010). Academic reforms have, in the majority of Gulf countries, resulted in an uncritical adoption of Western(mainly American) university curricula, content, and teaching practices, all of which have not always met the needs of the learners (Mazawi, 2003). As a result, an Islamized English curriculum often ensues, and consequently, learners experience a culture shock when studying in an American university since their English and western education is not equivalent to the actual English language and western culture in America. Bahgat (1999) mentioned that Omani's male illiteracy rate was twice that of Saudi's and three times Emirati's.

In addition, the Prophet Mohammed directed his followers to search for knowledge, including knowledge characteristic of non-Muslims and broader education in general. International graduate students have become an integral part of many major U.S. universities and their adaptation to American academic and social cultures can be an arduous task (Gonzalez, 2004) but even so, international graduate students from the Gulf actively pursue education in America.

\section{Language Adjustment}

Although realizing the importance of English, Gulf region international students mostly reported having difficulty with writing. Holmes ( 2005) said that "inadequate language skills have been found to mask other problems stemming from other causes such as lack of familiarity with a new educational and social environment, and with a new culture and its associated cultural norms and behavior" (p. 294). Mallinckrodt and Wang ( 2006) stated that "international students who have higher self- rated English abilities and have resided longer in the United States tend to be more acculturated with American culture and experience less sociocultural difficulty and less psychological distress" ( $\mathrm{p}$. 431).

\section{RESEARCH DESIGN AND METHOD}

The focus of this research is a comparative study of Saudi and Emirati students who transition into U.S. universities. The main purpose of this study is exploring the impact of students' and teachers' support on Emirati and Saudi students at U.S. Universities. This is a mixed-method research design that combines quantitative and qualitative strategies involving surveying 250 students followed by interviews. The present qualitative strategy provided an opportunity for the voices of Emirati and Saudi students to emerge. It gave a descriptive analysis of the cultural and social experiences of six Emirati and Saudi students who were selected for interviews. The interviews were coded to themes for analysis. This study is part of a larger study that examines academic socialization and cultural adjustment process of Emirati and Saudi students in the U.S. Universities.

\section{RESUlts}

This section presents some of the findings of the questionnaire and the interviews.

\section{A. Survey}

The main results that the questionnaire indicates are as followed. The results discuss the support that Emirati and Saudi students received from some American and Gulf region students, and their teachers.

\section{American Students' Support}

When Emirati and Saudi students indicated their preferences for collaborating with native English speakers for class presentation or writing projects, the highest number of Emirati students (40.2\%) and Saudi students (36.9\%) indicated a greater preference for working with native English speakers for presentation or writing projects. Differences between Saudi and Emirati students were significant for preferences for collaborating with native English speakers for class presentations or writing projects. Emirati students' reported preference $(\mathrm{M}=2.20 ; \mathrm{SD}=1.22)$ as did Saudi students (M $=2.19, \mathrm{SD}=1.22)($ See Tables 1 and 2 , Figures 1$)$.

TABLE1.

ITEM 1 (WORKING WITH NATIVE SPEAKERS) RESPONSES BY PERCENTAGE

\begin{tabular}{|c|c|c|c|c|c|c|}
\hline Option & & $\begin{array}{l}\text { More } \\
\text { Preferable }\end{array}$ & Preferable & Less Preferable & Sometimes & It Does Not Matter \\
\hline \multirow{2}{*}{ Country } & SA (122) & $36.9 \%$ & $30.3 \%$ & $16.4 \%$ & $9.8 \%$ & $6.6 \%$ \\
\hline & UAE and SA (214) & $38.9 \%$ & $28.6 \%$ & $16.7 \%$ & $7.3 \%$ & $8.5 \%$ \\
\hline
\end{tabular}


TABLE 2

INDEPENDENT T-TEST RESULTS FOR ITEM 1 (WORKING WITH NATIVE SPEAKERS).

\begin{tabular}{|c|c|c|c|c|c|}
\hline Country & $\mathrm{n}$ & Mean & Std. Deviation & $\mathrm{t}$ & $\mathrm{p}$ \\
\hline SA & 122 & 2.19 & 1.22 & .04 & .96 \\
\hline
\end{tabular}

Response scale: 1= More Preferable; $2=$ Preferable; $3=$ Less Preferable; 4= Sometimes; $5=$ It Does Not Matter.

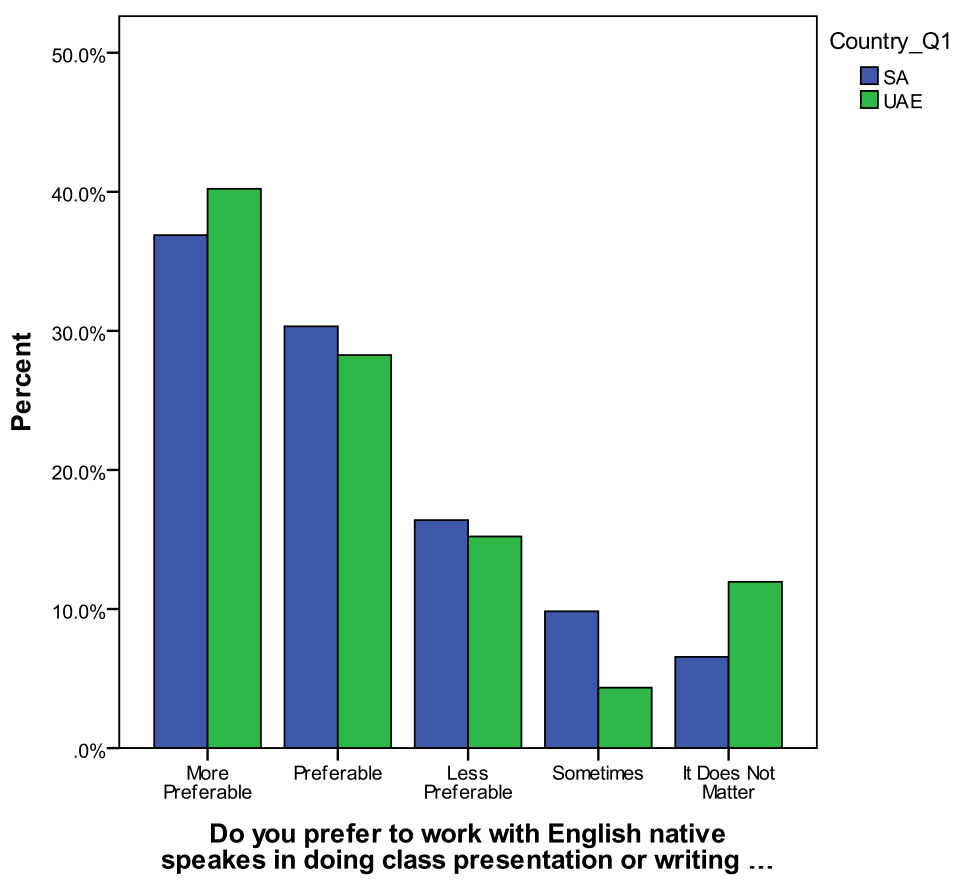

Figure 1. Item 1 (Working with native speakers) Responses by percentage

\section{Gulf Region Students' Support}

Academic socialization experience was also a study topic and the questionnaire caught responses related to classroom socialization, including comfort levels and their expectations for classes' activities. Specifically, this investigates the presence of the target populations' loyalties toward memberships in groups influential for decisions for associations for classroom activities. A single item was examined comfort levels for association with students from home regions. In terms of this comfort level, $31.2 \%$ of Emirati students felt "comfortable" associating with students from the same region; however, $31.7 \%$ of Saudi respondents emphasized that the region of peer-associates by choosing "It does not matter." Only $2.2 \%$ of Emirati students and $6.5 \%$ of the Saudi students expressed "uncomfortable" for working with regional peers (See Table 3).

TABLE 3.

ITEM 2(WORKING WITH GULF REGION STUDENTS) RESPONSES BY PERCENTAGE

\begin{tabular}{|c|c|c|c|c|c|}
\hline country & Very Comfortable & Comfortable & Less Comfortable & Uncomfortable & It Does Not Matter \\
\hline UAE & $28.0 \%$ & $31.2 \%$ & $15.1 \%$ & $2.2 \%$ & $23.7 \%$ \\
\hline Saudi Arabia & $14.6 \%$ & $29.3 \%$ & $17.9 \%$ & $6.5 \%$ & $31.7 \%$ \\
\hline $\begin{array}{l}\text { UAE and } \\
\text { Saudi Arabia }\end{array}$ & $20.8 \%$ & $29.7 \%$ & $16.5 \%$ & $4.7 \%$ & $28.4 \%$ \\
\hline
\end{tabular}

\section{Teachers' Support}

Concerning participants' accessibility to information, the questions pertain to the identities of types of individuals with whom respondents felt most comfortable communicating and associating during classes. Do students prefer work and communicate freely with Native American students or students from the Gulf Region or even the same gender? A further focus of attention was expertise and power relations which may be closely interdependent or correlated. Often, an individual with greater expertise has greater power; therefore, examination of expertise and power relations used two measures: knowledge and explicit, socially constructed hierarchical systems. Knowledge test items deal with the ideas of expertise and focus on respondents' perceptions of lack of academic knowledge or cultural knowledge, and professors' perception of an individual student. When asked to estimate the level of comfort when discussing challenges with professors, $70.9 \%$ of Emirati students were "very comfortable" and "comfortable"; however, $29 \%$ of Emirati 
students were "less comfortable" and "uncomfortable" when sharing their difficulties with their professors. In comparison, when evaluating the level of comfort when discussing challenges with their professors, $64.3 \%$ of Saudi students were "very comfortable" and "comfortable"; however, 35.8\% of Emirati students were "less comfortable" and "uncomfortable" sharing difficulties with professors (See Table 4).

TABLE 4

ITEM 3 (ACADEMIC DIFFICULTIES) RESPONSES BY PERCENTAGE Do you feel comfortable to discuss with your professors about your academic difficulties challenges?

\begin{tabular}{|l|l|l|l|l|l|}
\hline country & Very Comfortable & Comfortable & Less Comfortable & Uncomfortable & It Does Not Matter \\
\hline UAE & $29.0 \%$ & $41.9 \%$ & $25.8 \%$ & $3.2 \%$ & $.0 \%$ \\
\hline Saudi Arabia & $22.0 \%$ & $42.3 \%$ & $29.3 \%$ & $6.5 \%$ & $.0 \%$ \\
\hline $\begin{array}{l}\text { UAE and Saudi } \\
\text { Arabia }\end{array}$ & $24.9 \%$ & $41.4 \%$ & $28.7 \%$ & $5.1 \%$ & $.0 \%$ \\
\hline
\end{tabular}

\section{Preference for Individual Work}

When participants indicated their comfort levels for working independently in class, $41.3 \%$ of Emirati students emphasized that they are " very comfortable" in working independently. Similarly, 30.0\% of the Saudi students stated feeling "very comfortable" working independently. No significant differences in means were apparent between Saudi and Emirati students regarding comfort with independently work (See Tables 5 and 6)

TABLE 5.

ITEM 4 (INDEPENDENT WORK) RESPONSES BY PERCENTAGE

\begin{tabular}{|c|c|c|c|c|c|c|c|}
\hline country & $\begin{array}{l}\text { Very } \\
\text { Comfortable }\end{array}$ & Comfortable & $\begin{array}{l}\text { Less } \\
\text { Comfortable }\end{array}$ & Uncomfortable & $\begin{array}{l}\text { Sometimes } \\
\text { Uncomfortable }\end{array}$ & $\begin{array}{l}\text { Very } \\
\text { Uncomfortable }\end{array}$ & $\begin{array}{l}\text { It Does Not } \\
\text { Matter }\end{array}$ \\
\hline The UAE & $41.3 \%$ & $25.0 \%$ & $7.6 \%$ & $3.3 \%$ & $8.7 \%$ & $7.6 \%$ & $6.5 \%$ \\
\hline The Saudi Arabia & $30.0 \%$ & $28.3 \%$ & $19.2 \%$ & $7.5 \%$ & $7.5 \%$ & $2.5 \%$ & $5.0 \%$ \\
\hline $\begin{array}{l}\text { The UAE and } \\
\text { Saudi Arabia }\end{array}$ & $33.3 \%$ & $27.3 \%$ & $13.4 \%$ & $6.1 \%$ & $8.2 \%$ & $5.6 \%$ & $6.1 \%$ \\
\hline
\end{tabular}

TABLE 6.

INDEPENDENT T TEST RESULTS FOR ITEM 4 (INDEPENDENT WORK)

\begin{tabular}{|l|l|l|l|l|l|l|}
\hline In class, I am most comfortable doing...-working independently & & & Mean & Std. Deviation & t & Cohen's d \\
\hline Country & $\mathrm{n}$ & 2.65 & 1.67 & 0.09 & 0.93 & na \\
\hline SA & 120 & 2.62 & 2.00 & & & \\
UAE & 92 & &
\end{tabular}

Response scale: $1=$ Very comfortable; $2=$ Comfortable; $3=$ Less Comfortable; $4=$ It Does Not matter; $5=$ Sometimes Uncomfortable; $6=$ Uncomfortable; $7=$ Very Uncomfortable. na $=$ not applicable, t-test results, $\mathrm{p}>.05$

\section{B. Interview Results}

This section presents some of the interview analysis to mainly four themes.

\section{Theme 1: Communication Challenges with American Students}

Different communication skills might influence students' relationships especially if they come from different cultures. For instance, Emirati student "Zayed" experienced ignorance from American students and Saudi student "Khalifah" emphasized the American students' preference to work with their American peers:

Zayed commented:

I am talkative in the classroom. Some American students do not like to communicate with us. Other American students just communicate with us in our group work. They do not like to know us.

Zayed wonders whether the American students' have a fear regarding communicating with international students in general.

American students have no rapport with us. They may not be used to communicate with us or they may be afraid of us. I see American students communicate effectively with each other. American students do not communicate well with international students.

Khalifah that his observation relates to American student preferences for working in class assignments with fellow American students;

American students prefer to work with each other. I do not know the reason. Also, some of them work part-time which complicates our meeting to do our work.

\section{Theme 2: Arabs' Negative Influence on Their Peers}

Learning English is one of Emirati and Saudi students' main goals when coming to the U.S. The existence of Arabs surrounding these students increases opportunities for practicing English, especially in language preparation programs especially if the Arabs students are mocking on each other. That is when we make mistakes we should be working with each other to learn English and improve our communications in English. However, that does not necessarily happen. 
Hassan indicated this opportunity may not be utilized.

"Our problem is here we have many Arabs so we speak Arabic most the time."

Khalifah commented that sometimes fellow Arab students are not helpful at all.

When I made mistakes, Arabs students laugh at me. Therefore, I was shy to talk in the classroom. Once, I had a fight with an Arab student because he was laughing at me. I asked him: "Why are you laughing? "He did not give me any response

\section{Theme 3: Socialization with Americans}

Emirati and Saudi students socialize with Americans in their daily lives. These socialization experiences influence the students' adjustments to American culture. When the students receive respect from Americans, the students enjoy their residences and school. Positive socialization processes in classrooms transfers to strong relationships outside the classroom. Emirati and Saudi students will ask American students for support, which leads Emirati and Saudi students prefer to work with Americans.

Americans' Respect

Hassan expressed his fondness for Americans' morals and respect. He did not experience any kind of discrimination. Hassan commented:

My way of thinking has changed for the better. Honestly, I like the Americans' ethics such as respecting other people and respecting the system in general. The system is respected everywhere. I mean they respect the person they talk to. They really respect people. There are some exceptions but I did not find rude people at Penn State. I have been here a year and a half and thank God, I did not have any problems with people here. In any place I go, I feel that I am respected. Even in the immigration, I feel respected. They treat us with respect.

American friends

Hoor's adjustment to the American culture was smooth because she had some American friends when she was in private school. She even celebrated American ceremonies. Hoor commented:

I had American friends before I came to the U.S. I know them from when I was in private schools. I saw their pictures and discussed their culture. We used to celebrate Thanksgiving when I was in private school. When I came here, I did not find a big difference.

Socialization with American students

Sheikha described her adaptation experiences in socializing with American students. She commented:

The first time when I communicated with American students, I felt expatriated but now I am more comfortable to work with American students because I started to understand their communication style. American students considered me shy even though everyone knows that I am not shy.

Classroom socialization strengthens Zayed's relationship with American students outside the classroom, as he described:

I was walking on campus. Three American girls who were my classmates saw me and said, "Hi," and asked me about my classes. These students know me because I helped them when they needed some clarifications for some assignments

Zayed added:

In small classes, we usually communicate with American students and know them well.

The dormitory is a way of strengthening the relationship between Gulf region's students and American students, as Zayed commented:

Some of my friends told me that if I stayed at the dorm, American students might communicate well with us.

American students' assistance to Emirati students for writing

Saudi students seek assistance from American students for writing, especially in group work, as Khaled stated:

I have the ideas in Arabic and I do not know how to write them. I try to tell the information to the American student. He does not know Arabic so, it is difficult to deliver the idea to him. I ask help from American students in our group. I tell them that I want to write this and this so, how can I write it? Another option is that I will write it by myself and then ask the American students to edit it.

Writing is a challenge for Emirati and Saudi students, so having American students in their groups provides the Emirati and Saudi students with confidence to complete better work. Zayed commented:

During this summer, we have American classmates in our group. They wrote the report. We did the presentation. We brought the needed materials.

Preference for working with Americans (Native Speakers of English)

Emirati and Saudi students expressed their preference for collaborating with American students:

Khaled commented

I prefer to work with American students.

Zayed commented:

I prefer to work with American students because they do their work well. We communicate through e-mails and divide the work. Everyone will do his/ her work which is fair. Some Americans do not want to work but others want to study and do their work.

4. Theme 4: Teachers' Socialization and Support

Teachers support the Emirati and Saudi students' participation, writing papers, and examinations 
Khalifah commented:

My teachers were supporting me. They encourage me to be relaxed when speaking. They told me the important strategy to learn English is continually practicing.

Khalifah expressed his teacher's understanding of their difficulties:

The teacher was very cooperative and when we have questions, we go to her. The teacher told us that she will help us in our research paper and will give us the main points to focus on.

Hoor commented:

Some classes, the teachers will be available during test time, so we can ask him/her and he/she will explain to us. $\mathrm{He} / \mathrm{she}$ can remind us of what we have taken and in which section, which is better than the computer-based test, for which we cannot contact the teacher or use Google to search for information or translate some words.

Zayed expressed his comfort level in discussing his difficulties with his teacher:

If I have questions, I will ask my teacher. Sometimes, to prepare for exams, I answer the exam sample and if I have some mistakes, I show it to my teacher for an explanation of my mistakes.

Zayed discovered that American teachers do not discriminate against Arabs, a fear he had when attending American University. He commented:

The teachers are friendly if we are friendly. Although, I expected that some American teachers would discriminate against Arab students, as I heard, but I did not find that.

Emirati female student "Hoor" expressed how her teachers try to facilitate her learning by providing summaries and providing training for some programs. Also, she mentioned the important role of the teaching assistants.

Hoor commented:

Instead of buying books, teachers give us materials, summaries of the important points in the books with some information which the teachers create from different resources. We do not need to read the books. These readings with my notes are important for study.

Hoor added:

My major is biology. I used some database for writing my research. Our teachers teach us how to use these databases and guide us on the process of using the databases. Before using any programs, teachers teach us how to use them. Also, if we find difficulties in using these programs and databases, teaching assistants help us as well. We have to go to the teaching assistants early before the class starts.

Hassan mentioned his experience with the language institute support:

I have only an advisor in the language institute who is responsible for solving the students' issues. He is responsible for checking the students' absences. The advisor will send an e-mail to ask the student what the problems he/she faces that makes him absent. From my personal experience of the language institute, the first semester, I had a problem in my country and I went back home. I did not start the semester. I was absent for three weeks. I told the Saudi Arabian Embassy about my situation and I travelled. I stayed three or four weeks in Saudi Arabia and went back. I think I missed more than five weeks. The semester was only 40 classes. Only 20 classes are the limit to be absent in the language institute. I completed the semester and I returned after 20 days. The language institute accepted my situation and I competed the semester. Also, in another semester, I was playing football and I had accident. My leg was broken. I went to the hospital and I was absent for three weeks for a sickness absence. They accepted the situation. They are cooperative if a student is following the rules. If a student is playing and does not come to class, they will expel him. They had already expelled some students because of absence. If a teacher gives a student a warning for a semester and he/she gives him another warning in the following semester, the student will be spelled too. That is evidence that they have rules and they follow these rules.

The need for Arab teachers

Emirati and Saudi students have different opinions about having Arabs teachers. Some students have good experiences; however, a Saudi student stated his preference for native English speakers in his language preparation program to teach English.

Khalifah commented:

My friends' advisor in Architecture Engineering was Arab. He helped them many times.

Hoor commented:

We do not have Arabs teachers. I think if we have Arabs teachers, it will be better. They will understand our linguistics difficulties and will try to explain the complex concepts.

Hassan commented:

We do not have Arabs teachers in the language institute. I do not prefer to have Arabs teachers because I want to not to use Arabic any more to learn.

\section{DisCUSSION AND CONCLUSIONS}

The major findings of this study allow discussion of the impact of students' and teachers' support on Emirati and Saudi students at U.S. Universities. Support was one of the four issues, which doctoral students addressed in a study of understanding their disciplinary context and cultural impact on their socialization and attrition at one institution (Gardner, 2010). Khalifah, a Saudi student, expressed his teachers' support: "My teachers were supporting me. They 
encourage me to be relaxed to speak. They told me the important strategy to learn English is continually practicing." He expressed his teacher's understanding of the students' difficulties: "The teacher was very cooperative and when we have questions, we go to her. The teacher told us that she will help us in our research paper and will give us the main points to focus on." Hoor, an Emirati female student, also described her teachers' support: "Some classes, the teachers will be available in the test time so, we can ask him/her and he/she will explain to us. He/she can remind us of what we have taken and in which section, which is better than the computer based test which we cannot contact the teacher or use Google to search for information or translate some words." Zayed, an Emirati student, expressed his comfort level in discussing his difficulties with his teacher: "If I have questions, I will ask my teacher. Sometimes, to prepare for exams, I answer the exam sample and if I have some mistakes, I show it to my teacher to explain my mistakes." Supporting the Emirati and Saudi student in their disciplines facilitates their socialization in their academic community. The study implied that U.S. universities need to hire more Arab professors and teaching assistants to support the Emirati and Saudi students in their studies because they will understand the language and culture. Also, these Arab teachers will help Emirati and Saudi students attain admission because of the common interest.

\section{REFERENCES}

[1] Barton, D., \& Hamilton, M. (1998). Local literacies: Reading and writing in one community. London: Routledge.

[2] Belcher, D. (1994). The apprenticeship approach to advanced academic literacy: Graduate students and their mentors. English for Specific Purposes, 13, 23-34

[3] Bloome, D., Carter, S.P., Christian, B.M, Otto, S. \& Shuart-Faris, N.(2005). Discourse analysis and the study of classroom language and literacy events- A micro ethnographic perspective. New Jersey: Lawrence Erlbaum.

[4] Canagarajah, S. (2002a). Multilingual writers and the academic community: towards a critical relationship. Journal of English for Academic Purposes, 1, 29-44.

[5] Canagarajah, A. S. (2002b). Critical academic writing and multilingual students. Ann Arbor, MI: University of Michigan Press.

[6] Casanave, C. P. (1995). Locating interactions: Constructing contexts for composing in a graduate sociology program. In D. Belcher \& G. Brain (Eds.), Academic writing in a second language. Essays on research \& pedagogy (pp. 83-110). Norwood, NJ: Ablex.

[7] Casanave, C. P. (2002). Writing games: Multicultural case studies of academic literacy practices in higher education. Mahwah, NJ: Lawrence Erlbaum.

[8] Charles-Toussaint, G. C., \& Crowson, H. M. (2010). Prejudice against international students: the role of threat perceptions and authoritarian dispositions in U.S. students. Journal of Psychology, 144 (5), 413-428.

[9] Furnham, A., \& Bochner, S. (1986). Culture shock: Psychological reactions to unfamiliar environments. London: Methuen.

[10] Gardner, S. K. (2010). Contrasting the socialization experiences of doctoral students in high- and low-completing departments: A qualitative analysis of disciplinary contexts at one institution. The Journal of Higher Education, 81(1), 61-81.

[11] Gee, J.P. (2000). The New literacy Studies: from socially situated to the work of the social. In D. Barton, M. Hamilton and R. Ivanic (Eds.) Situated Literacies: Reading and writing in context (pp. 180-197). London: Routledge.

[12] Gonzalez, V. (2004). Second language learning: Cultural adaptation processes in international graduate students in U.S. universities. Lanham, MD: University Press of America.

[13] Church, A. T. (1982). Sojourner adjustment. Psychological Bulletin, 91, 540-572.

[14] Gumperz, J.J. (2001). Interactional Sociolinguisitics: A personal perspective. In D. Schiffrin, D. Tannen, \& H.E. Hamilton (Eds.) Handbook of discourse analysis. (pp.215-229). Blackwell Publishers.

[15] Hirvela, A., \& Belcher, D. (2001). Coming back to voice. The multiple voices and identities of mature multilingual writers. Journal of Second Language Writing, 10,83-106.

[16] Hymes, D. (1974). The foundations of sociolinguistics: Sociolinguistic ethnography. Philadelphia: University of Pennsylvania Press.

[17] Ivanic, R. \& Camps, D. (2001). I am how I sound: Voice as self-representation in L2 writing. Journal of Second Language Writing, 10(1-2), 3-33.

[18] Ivanic, R. (1998). Writing and identity: The discursive construction of identity in academic writing. Amsterdam: John Benjamins.

[19] Kim. U. (1988). Acculturation of Korean immigrants of Canada. Unpublished Doctoral Dissertation, Queen's University. Canada.

[20] Lea, M. R. \& Street, B. (1999). Writing as academic literacies: Understanding textual practices in higher education. In C.N. Candlin and K. Hayland (Eds.), Writing texts, processes and practices (pp. 62-81). Essex, UK: Longman.

[21] Mazawi, A.E. (2003). Public Arab Gulf universities, in Altback, P.G. (Ed.), The Decline of the Guru: The Academic Profession in the Third World, Palgrave Macmillan, New York, NY, pp. 231-70.

[22] UNESCO. (2009). Global Education Digest 2009. UNESCO Institute for Statistics, Montreal/Paris.

[23] Oberg, K. (1955). Types of Social Structure among the Lowland Tribes of Central and South America. American Anthropologist 57: 472-87

[24] Ward, C. \& Searle W. (1990). The Prediction of Psychological and Sociocultural Adjustment During Cross-cultural Transitions, International Journal of Intercultural Relations, 14, 449-464.

[25] Ward, C., \& Searle, W. (1991). The impact of value discrepancies and cultural identity on psychological and sociocultural adjustment of sojourners. International Journal of Intercultural Relations, 15(2), 209-225. 
Ghadah Al Murshidi, is currently an assistant professor in Curriculum and Instruction Department, She was a faculty member in Linguistics department, the Social Sciences and Humanities College. Her Ph.D. study was in Curriculum and Instruction and Comparative and International Education, her Master degrees are in Educational Leadership and Applied Linguistics, are from Pennsylvania State University. Her Bachelor Degree in Applied Linguistics and her Professional Diploma in Education are from the UAE University. Her research interests are in academic socialization, Language socialization, Cultures, leadership, etc. Her recent publications are The Expression and Conceptualization of Motion through Space and Manner of Motion in Arabic and English: A Comparative Analysis, and Emirati and Saudi Students' Cultural Socialization and Adjustment at U.S. Universities. Her recent award was "Young Emirati Researchers Prize" (YERP 2013) competition. 